\title{
RADIOCARBON DISPERSION AROUND CANADIAN NUCLEAR FACILITIES
}

\author{
G. M. MILTON, S. J. KRAMER, R. M. BROWN, C. J. W. REPTA, K. J. KING and R. R. RAO
}

AECL Research, Chalk River Laboratories, Chalk River, Ontario, Canada, K0J $1 \mathrm{JO}$

\begin{abstract}
Canadian deuterium uranium (CANDU) pressurized heavy-water reactors produce ${ }^{14} \mathrm{C}$ by neutron activation of trace quantities of nitrogen in annular gas and reactor components $\left({ }^{14} \mathrm{~N}(\mathrm{n}, \mathrm{p}){ }^{14} \mathrm{C}\right)$, and from ${ }^{17} \mathrm{O}$ in the heavy water moderator by $\left({ }^{17} \mathrm{O}(\mathrm{n}, \alpha){ }^{14} \mathrm{C}\right)$. The radiocarbon produced in the moderator is removed on ion exchange resins incorporated in the water purification systems; however, a much smaller gaseous portion is vented from reactor stacks at activity levels considerably below $1 \%$ of permissible derived emission limits. Early measurements of the carbon speciation indicated that $>90 \%$ of the ${ }^{14} \mathrm{C}$ emitted was in the form of $\mathrm{CO}_{2}$. We conducted surveys of the atmospheric dispersion of ${ }^{14} \mathrm{CO}_{2}$ at the Chalk River Laboratories and at the Pickering Nuclear Generating Station. We analyzed air, vegetation, soils and tree rings to add to the historical record of ${ }^{14} \mathrm{C}$ emissions at these sites, and to gain an understanding of the relative importance of the various carbon pools that act as sources/sinks within the total ${ }^{14} \mathrm{C}$ budget. Better model parameters than those currently available for calculating the dose to the critical group can be obtained in this manner. Global dose estimates may require the development of techniques for estimating emissions occurring outside the growing season.
\end{abstract}

\section{INTRODUCTION}

In addition to the natural cosmogenic production of radiocarbon, the atmospheric content of this radioisotope has been augmented in the 20th century by anthropogenic contributions from nuclear weapons testing and, to a much lesser extent, emissions from nuclear reactors. Considerable international effort has been put into quantifying this reactor contribution, as well as estimating the relative proportions of oxidized and reduced forms of carbon released from various reactor designs (e.g., Wahlen and Kunz 1978; Kabat 1978). More recently, there has been renewed interest in refining such measurements, in response to the need for more accurate (less conservative) estimates of dose from increasing nuclear power production (e.g., Joshi, Ramamirtham and Soman 1987; Curtis and Guest 1988; Uchrin et al. 1992).

The most comprehensive dispersion study of stack-emitted ${ }^{14} \mathrm{CO}_{2}$ was made by Otlet, Walker and Fulker (1990), who measured dispersion around the reprocessing site at Sellafield, in air, food and hawthorn berries. Levin et al. (1988) measured the environmental distribution of reactor ${ }^{14} \mathrm{CO}_{2}$ around two German nuclear power plants, and compared measured dispersion factors with values calculated using a one-dimensional Gaussian plume model. Several researchers studied carbon dynamics in soils, utilizing the 1960 s input of ${ }^{14} \mathrm{C}$ to the biosphere during nuclear weapons testing (e.g., O’Brien 1984; Harkness, Harrison and Bacon 1986; Jenkinson et al. 1992; Trumbore 1993). However, we know of no report in the literature synthesizing emissions, biomass accumulation, soil deposition and soil residence times at a reactor site. We are collecting data required for such a synthesis at two different sites of chronically low-level ${ }^{14} \mathrm{C}$ emission, the Chalk River Laboratories (CRL) and the Pickering Nuclear Generating Station (PNGS) (Fig. 1). Table 1 summarizes the general characteristics of the climate, soil and vegetative conditions at the two sites.

Here we summarize the existing data and detail our more recent measurements. Much of this is work in progress. In addition to providing more accurate parameters for existing dose-assessment models, we believe such data, when complete, can provide valuable input to current studies of global carbon cycling. 
The following key questions provide the focus for our study:

1. Can we estimate the total amount of ${ }^{14} \mathrm{C}$ released during reactor operations if emission records are unavailable?

2. Is the assumption that the ${ }^{14} \mathrm{C}$-specific activity of growing vegetation parallels that of the ambient air always valid near operating reactors?

3. Is a significant portion of the ${ }^{14} \mathrm{C}$ taken up by growing vegetation accumulating in the local soils?

\section{DESCRIPTIVE BACKGROUND}

Most of the ${ }^{14} \mathrm{C}$ produced in the Canadian deuterium uranium (CANDU) pressurized heavy-water reactors (PHWR) results from the large inventory of ${ }^{17} \mathrm{O}$ in the heavy-water moderator. Table 2 lists the relative importance of ${ }^{14} \mathrm{C}$ production and emission from reactor component sources such as moderator, primary coolant, annulus gas and fuel in CANDU-6 (600 MWe) reactors. The ${ }^{14} \mathrm{C}$ produced in the moderator is removed on ion-exchange resins incorporated in the water purification systems; however, the much smaller gaseous portion is vented from reactor stacks at activity levels considerably below $1 \%$ of the permissible derived emission limits.

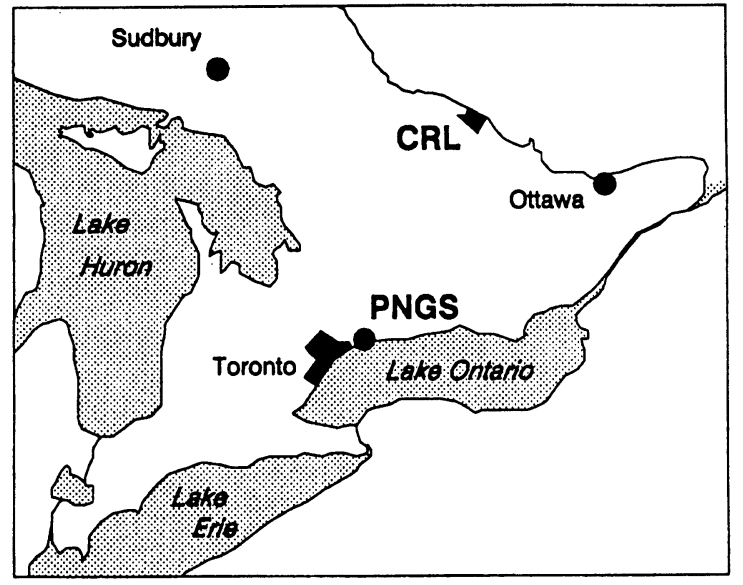

Fig. 1. Map of southern Ontario, indicating the geographic location of our two study areas

TABLE 1. General Characteristics of the Two Study Sites

\begin{tabular}{|c|c|c|c|c|c|c|}
\hline Site & $\begin{array}{l}\text { Latitude, } \\
\text { principal } \\
\text { land use }\end{array}$ & $\begin{array}{l}\text { Climate/ } \\
\text { temperature, } \\
\text { precipitation, } \\
\text { climate zone }\end{array}$ & Soil type & $\begin{array}{l}\text { Underlying } \\
\text { rock }\end{array}$ & Vegetation & $\begin{array}{l}\text { Net primary } \\
\text { productivity } \\
\left(\mathrm{g} \mathrm{C} \mathrm{m}^{-2} \mathrm{a}^{-1}\right)\end{array}$ \\
\hline Pickering & $\begin{array}{l}40^{\circ} \mathrm{N}, \\
\text { suburban } \\
\text { housing, } \\
\text { agriculture }\end{array}$ & $\begin{array}{l}-20 \text { to } 30^{\circ} \mathrm{C} \\
-830 \mathrm{~mm} \\
90 \% \text { rain } \\
10 \% \text { snow } \\
\text { Zone } 5(\mathrm{a})^{*}\end{array}$ & $\begin{array}{l}\text { Brown } \\
\text { luvisol }\end{array}$ & $\begin{array}{l}\text { St. Lawrence } \\
\text { platform } \\
\text { paleozoic } \\
\text { shales, } \\
\text { carbonates }\end{array}$ & $\begin{array}{l}\text { Deciduous } \\
\text { trees/scrub/ } \\
\text { grass }\end{array}$ & $240-560 \dagger$ \\
\hline $\begin{array}{l}\text { Chalk } \\
\text { River }\end{array}$ & $\begin{array}{l}46^{\circ} \mathrm{N}, \\
\text { lumbering }\end{array}$ & $\begin{array}{l}-30 \text { to } 30^{\circ} \mathrm{C} \\
-900 \mathrm{~mm} \\
80 \% \text { rain } \\
20 \% \text { snow } \\
\text { Zone } 4(\mathrm{~b})^{*}\end{array}$ & $\begin{array}{l}\text { Podzol } \\
\text { forest litter on } \\
\text { postglacial } \\
\text { sands and tills }\end{array}$ & $\begin{array}{l}\text { Precambrian } \\
\text { granites and } \\
\text { gneisses }\end{array}$ & $\begin{array}{l}\text { Moist } \\
\text { temperate } \\
\text { forest/scrub }\end{array}$ & $240-560 \dagger$ \\
\hline
\end{tabular}

*Canadian Department of Agriculture

†From Whittaker and Likens (1973)

PNGS-A began operating in 1971, PNGS-B in 1983. Maruska (1981) first reported ${ }^{14} \mathrm{C}$ emissions from this station; measurements taken over the full year were compared with those predicted from the operational data for the same period. Although compliance monitoring of stack emissions has 
been required only at PNGS-A, environmental monitoring in the vicinity of the station has been performed since 1979. The heavy-water research reactors at CRL (NRX and NRU), in operation since 1947 and 1957, respectively, differ considerably in design from the CANDU power reactor. Because the levels of ${ }^{14} \mathrm{C}$ at this site are far below derived emission limits, routine monitoring has never been undertaken for this radionuclide. The first CRL environmental survey for ${ }^{14} \mathrm{C}$ was conducted in 1982-1983, the second in 1993. Stack emissions were also measured directly for a 5-day period during 1993. New stack-monitoring equipment, permitting the identification of oxidized and reduced forms of carbon, was developed in 1994, and an extended series of measurements was carried out over a 3-week period.

TABLE 2. Estimated ${ }^{14} \mathrm{C}$ System Distribution for CANDU-6*

\begin{tabular}{lccc}
\hline System & \% of production & \% emitted & \% on resins \\
\hline Annulus gas & 0.13 & 0.13 & 0.0 \\
Moderator & 95.2 & 3.77 & 91.43 \\
Primary heat transport & 1.3 & 0.0 & 1.3 \\
Fuel & 3.37 & 0.0 & 0.0 \\
\hline *Reprinted by permission of the authors from ACRP-14 (in press) &
\end{tabular}

\section{MethodS}

Soil samples are pretreated according to the procedure outlined in Harkness, Harrison and Bacon (1986). For soil density fractionation, we use sodium polytungstate, following the method of Trumbore (1993). Milton and Brown (1993) described the methods we use to measure ${ }^{14} \mathrm{C}$ in environmental samples at CRL. In brief, $\mathrm{CO}_{2}$ in air is absorbed in trays containing $\mathrm{NaOH}$, exposed for a 2-week period. Vegetation and soil samples are combusted either in a Parr ${ }^{\mathrm{TM}}$ bomb or a Thermolyne ${ }^{\mathrm{TM}}$ tube furnace. The released $\mathrm{CO}_{2}$ is first captured in $\mathrm{NaOH}$, then, in all cases, re-released to a Carbo-Sorb ${ }^{\mathrm{TM}}$ / Permafluor $^{\mathrm{TM}}$ cocktail for liquid scintillation counting.

The accuracy of our measurements, determined by repeated analyses of NIST HOxII and IAEA quality assurance material C-3 (cellulose) is better than $\pm 5 \%$. One standard deviation of our reported values for high specific activity samples is $\pm 1.5 \%$; for near background levels it is $c a$. $\pm 10 \%$. Background levels subtracted in each survey were the average measurement of a suite of vegetative samples collected during that sampling year at Ontario and Quebec sites far from populated areas.

\section{RESULTS AND DISCUSSION}

\section{Emission Records and Dispersion Patterns}

\section{Pickering Nuclear Generating Station}

${ }^{14} \mathrm{C}$ emissions and environmental sampling at Ontario Hydro nuclear power stations have been summarized (ACRP 14, in press). A study of emissions from a PHWR of the CANDU design in India (Joshi, Ramamirtham and Soman 1987 ) revealed that the ${ }^{14} \mathrm{C}$ activity released was positively correlated with thermal power produced. By contrast, Maruska (1981) found a poor correlation between emissions and operational data at PNGS-A except for times of major moderator system maintenance. A detailed study of the degree of transfer of ${ }^{14} \mathrm{C}$ from moderator to cover gas, and its subsequent release via the stack, during cover gas purging, is planned for 1995.

Figure 2 presents the combined contour plot of several vegetation surveys made from 1980-1982 (Neil 1983). The isopleths show non-uniform patterns that correlate with the southwest winds off 


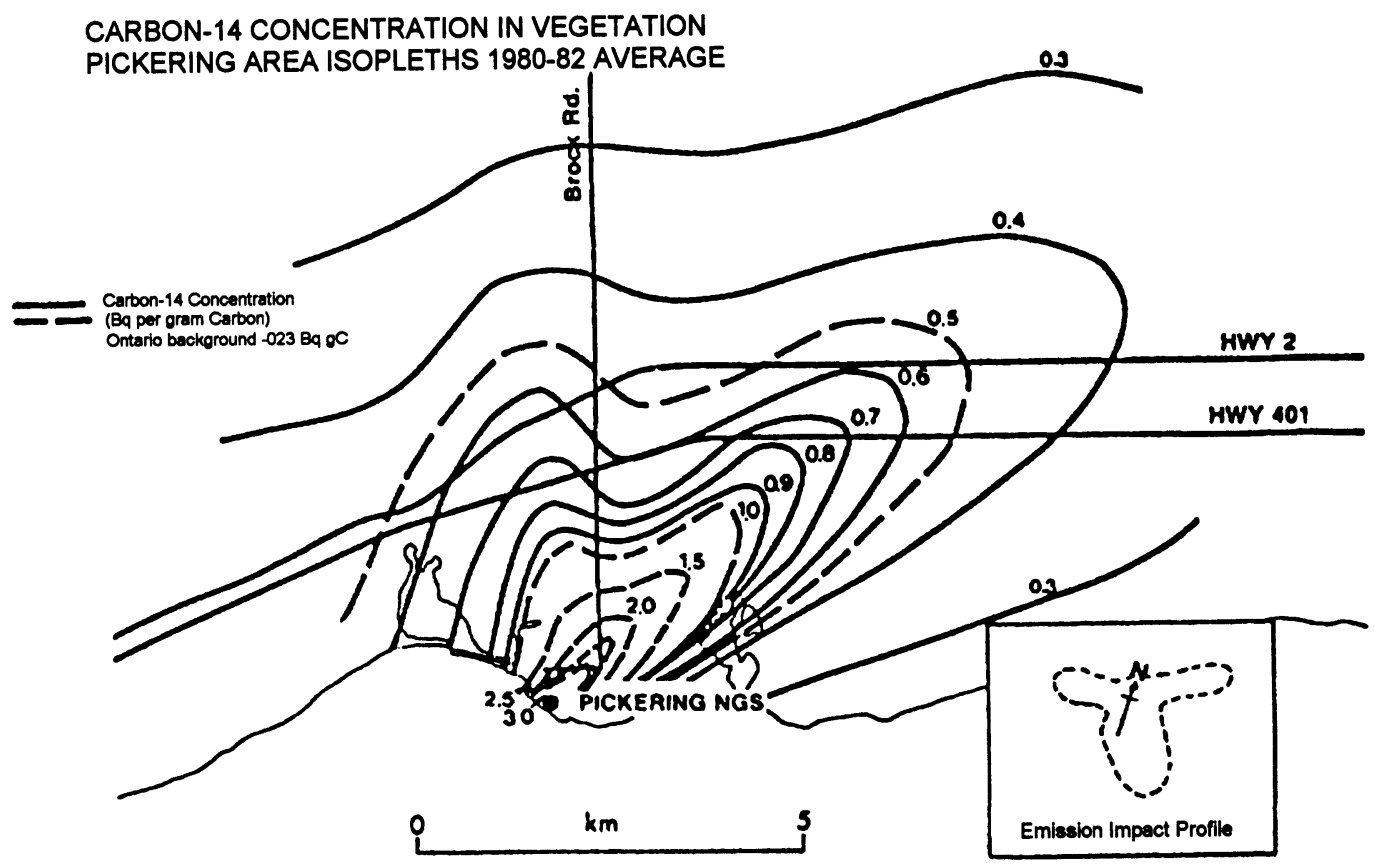

Fig. 2. A 3-yr average of ${ }^{14} \mathrm{C}$ dispersion surveys in the vicinity of PNGS. Reprinted with permission from Ontario Hydro Information Report SSD-IR-83-21.

Lake Ontario prevailing during the growing season, enhancing the concentrations in a northeasterly direction from the station. We extended vegetation sampling by $10 \mathrm{~km}$ in the two principal wind directions. Background levels are reached at $20 \mathrm{~km}$. Table 3 lists the mean dilution factors at three soil and vegetation sampling locations, in the principal wind directions.

Figure 3 shows the measured ${ }^{14} \mathrm{C}$ releases from PNGS and nearby environmental levels of ${ }^{14} \mathrm{C}$ in biota published by Ontario Hydro for 1982-1993. Environmental and stack measurements are not available for the early years of station operation. Initially, nitrogen was used as an annulus gas in these reactors.

TABLE 3. Mean Dilution Factors for Specific Sampling Sites

\begin{tabular}{llll}
\hline Site & Year & $\begin{array}{l}\text { Distance from } \\
\text { stack }(\mathrm{km})\end{array}$ & $\begin{array}{l}\text { Atmospheric } \\
\text { dilution factor } \\
\mathrm{K}_{\mathrm{a}}^{*}\left(\mathrm{~s} \mathrm{~m}^{-3}\right)\end{array}$ \\
\hline PNGS & 1991 & $0.9 \mathrm{NE}$ & $6.1 \times 10^{-6}$ \\
& 1991 & $1.0 \mathrm{NE}$ & $3.5 \times 10^{-6}$ \\
& 1993 & $1.3 \mathrm{NNW}$ & $6.0 \times 10^{-7}$ \\
$\mathrm{CRL}$ & 1993 & $0.25 \mathrm{E}$ & $1.5 \times 10^{-6}$ \\
& 1993 & $0.85 \mathrm{WNW}$ & $7.0 \times 10^{-7}$ \\
& 1993 & $0.70 \mathrm{ESE}$ & $3.3 \times 10^{-7}$ \\
& 1994 & $0.85 \mathrm{WNW}$ & $7.1 \times 10^{-7}$ \\
& 1994 & $0.70 \mathrm{ESE}$ & $3.3 \times 10^{-7}$ \\
\hline
\end{tabular}

${ }^{*} \mathrm{~K}_{\mathrm{a}}=\mathrm{C} / \mathrm{Q} ; \mathrm{C}=$ annual average ${ }^{14} \mathrm{C}$ in air concentration $\left(\mathrm{Bq} \mathrm{m}^{-3}\right) ; \mathrm{Q}=$ average

${ }^{14} \mathrm{C}$ release rate $\left(\mathrm{Bq} \mathrm{s}^{-1}\right)$ 
This was totally changed to $\mathrm{CO}_{2}$ between 1988 and 1992; thus, this source of ${ }^{14} \mathrm{C}$ production is now almost negligible compared with the moderator system. The increase in measured levels in biota in 1992 indicated in Figure 3 is inconsistent with the previous year's data and with the reported releases in 1992. However, $50 \%$ of that year's release of ${ }^{14} \mathrm{C}$ occurred during August and September. ${ }^{14} \mathrm{C}$-specific activities in leaves that we collected in mid-October 1992 were already down to levels similar to those of 1991 and 1993, whereas fruit and vegetables from the same plants, collected at the same time, carried the history of the high release during their period of maximum growth (Table 4; differences in specific activity in vegetables and fruit reflect differences in distance from the stack). These data illustrate more clearly than most surveys of this kind the difficulty of attempting to correlate the ${ }^{14} \mathrm{C}$ signal in growing vegetation with an average annual, or even average summer emission rate.

The annual tree-ring record might be expected to fall between the two extremes recorded above in leaves and fruit. Despite the potentially biased nature of this seasonal record, in the absence of emission release data, tree-ring chronologies offer one of the few promising methods of reconstructing such information (e.g., Otlet, Longley and Walker 1989). These authors discussed in more detail the inherent shortcomings of using this technique. Our tree-ring data from a tree growing next to the vegetable plot $1 \mathrm{~km}$ northeast of PNGS (Fig. 3) also show good correlation with the annual environmental monitoring data. As stated above, a short release at the height of the growing season can provide a distorted picture for emission reconstruction, but the use of tree-ring records for estimation of biomass accumulation of ${ }^{14} \mathrm{C}$ remains on firm ground.

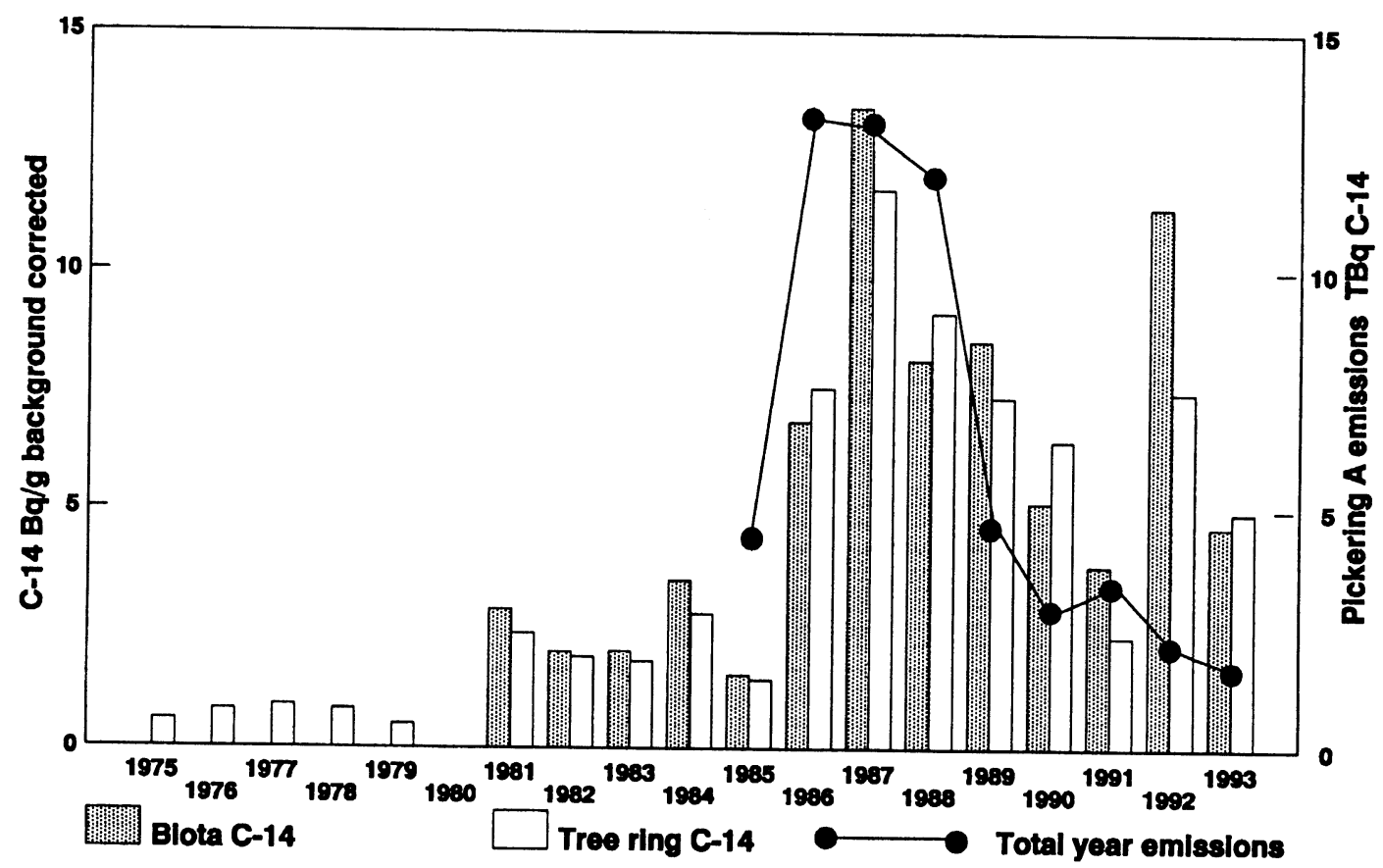

Fig. $3 .{ }^{14} \mathrm{C}$ monitoring data and a tree-ring chronology for PNGS, $1975-1993 . \longrightarrow$ = measured ${ }^{14} \mathrm{C}$ releases from PNGS; = nearby environmental levels of ${ }^{14} \mathrm{C}$ in biota published by Ontario Hydro for $1982-1993 ; \square=$ our tree-ring data from a tree growing next to the vegetable plot $1 \mathrm{~km} \mathrm{NE}$ of PNGS. Ontario Hydro emission and monitoring data reproduced with permission from ACRP-14. 
TABLE 4. Variation in Levels of ${ }^{14} \mathrm{C}$ in Fruit and Leaves of the Same Plant and Variation in ${ }^{14} \mathrm{C}$ with Time, PNGS Area

\begin{tabular}{|c|c|c|c|}
\hline \multirow[t]{2}{*}{ Sample } & \multicolumn{3}{|c|}{ Specific activity $\left(\mathrm{Bq} \mathrm{kg}^{-1}\right)$} \\
\hline & $9 / 92$ & $10 / 92$ & $8 / 93$ \\
\hline Tomato & 10,750 & 8390 & \\
\hline Apple-fruit & & 12,950 & 4890 \\
\hline Apple-leaves & & 5560 & 4510 \\
\hline Cranberry-fruit & & 10,475 & \\
\hline Cranberry-leaves & & 6160 & \\
\hline
\end{tabular}

\section{Chalk River Laboratories}

Stack emissions at CRL were not measured until 1993; thus, two vegetation surveys, conducted in 1982-1983 and 1993-1994, are our chief source of information on environmental levels of ${ }^{14} \mathrm{C}$ at this site. Figure 4 contains contour plots from these two surveys. The roughly elliptical shapes of the two plots are very similar, although the position of the $200 \mathrm{~Bq} \mathrm{~kg}^{-1}$ of carbon contour falls considerably closer to the stack in 1982 than 1993 . We believe such differences between the two surveys are more likely to result from variations in meteorological conditions than from substantial changes in total emissions. To estimate the contribution of ${ }^{14} \mathrm{C}$ production from air ingress, we have calculated ${ }^{14} \mathrm{C}$ emission rates solely on the basis of measured ${ }^{41} \mathrm{Ar}$ emission rates for similar periods. These are compared in Table 5 to the measured ${ }^{14} \mathrm{CO}_{2}$ emission rates. A factor of 4 to 5 exists between the calculated value and the mean measured values in both 1993 and 1994, calling into doubt our original assumption that the major producer of ${ }^{14} \mathrm{C}$ emissions was air in the annular spaces of the reactors, particularly of NRX, which was retired from service in 1992. Although we have indicated above that the ${ }^{14} \mathrm{C}$ produced in the moderator and primary coolant are removed on ion-exchange resins, both the Chalk River reactors suffer from recurring small leaks of these fluids into the reactor buildings. These are largely released subsequently as gas from the roof vents. We are currently surveying the ${ }^{3} \mathrm{H}$-monitoring data for those locations to look for correlations with measured variability in ${ }^{14} \mathrm{C}$ emissions. It may be difficult to assess the relative importance of the stack and roof vent emissions during any given set of meteorological conditions. Although we observed differences between daily stack emissions of both ${ }^{14} \mathrm{C}$ and ${ }^{3} \mathrm{H}$ during 5 days of stack sampling, we saw no correlations between the two in this source. The mean dilution factor based on the May 1993 data for emissions and air measurements at $0.25 \mathrm{~km}$ in the principal wind direction (Table 3 ) is greater than that measured at $1 \mathrm{~km}$ from the source at PNGS. This may simply reflect the higher elevation of the stack $(50 \mathrm{~m}$, on a topographic high, as opposed to $<20 \mathrm{~m}$ at PNGS). Bubbler and passive air sampling, which paralleled recent stack monitoring, has permitted more precise estimates of the dilution factor at specific CRL locations (Table 3).

In the 1982-1983 survey, we collected air and vegetation at a variety of sites over the growing season; in some cases, the difference between the specific activity of the two at a given site was high (mean of 10 sites, air/vegetation $=1.13 \pm 0.12$ ), but the pattern was inconsistent. ${ }^{13} \mathrm{C}$ measurements in our $\mathrm{NaOH}$ passive samplers indicated that the correction for isotopic fractionation would not account for $>2-3 \%$ discrepancy between air and vegetation. Because ${ }^{14} \mathrm{C}$ researchers (e.g., Cain and Suess 1976) have shown that the ${ }^{14} \mathrm{C}$ content of vegetation parallels that of the atmosphere at the time of growth, we did not anticipate such differences. We later learned that Levin et al. (1988) and Otlet (1992) had observed similar discrepancies during short-term sampling. When we again observed mean air/vegetation ratios $=1.22 \pm 0.21$ in our initial 2-week sampling period in 1993, Otlet and Walker (personal communication) advised us to continue the measurements at two sites over a full season, and also to 

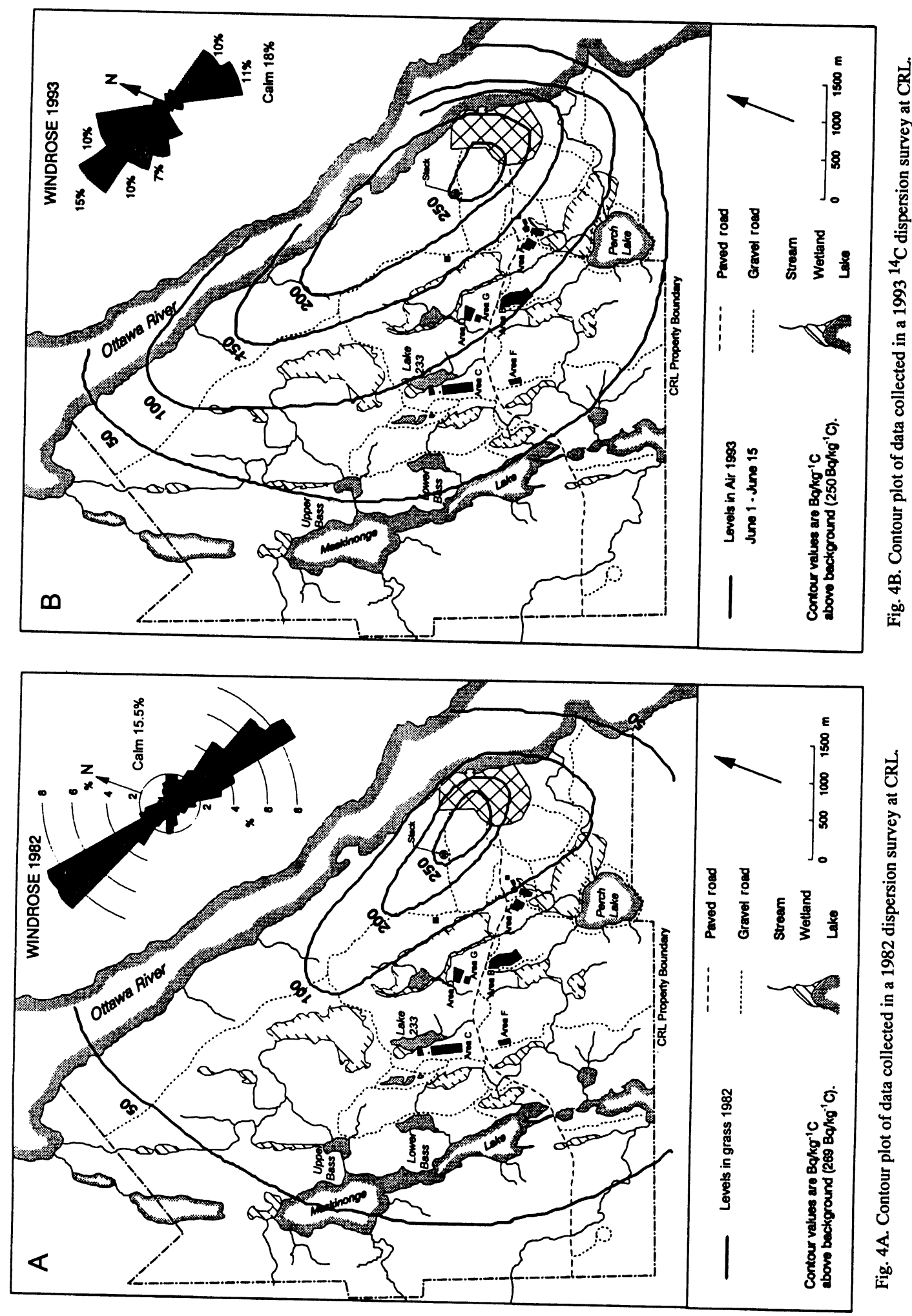
TABLE 5. Calculated and Measured Emission Rates of ${ }^{14} \mathrm{C}$ at CRL

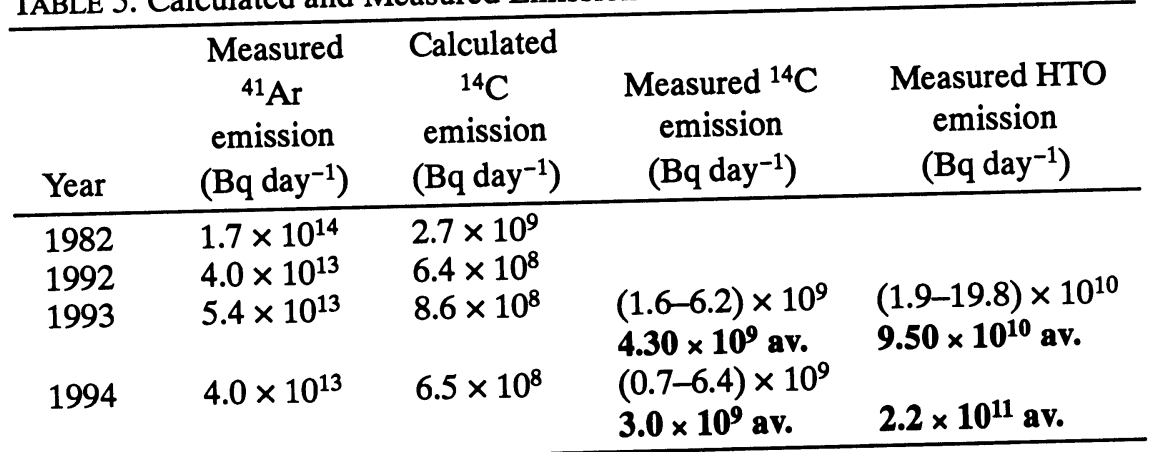

check for possible differences introduced by daylight only versus 24 -h sampling. (Levin et al. estimated this effect from differences in dispersion factors; we followed Otlet's suggestion of timers to control the exposure period of passive samplers.) Figure 5 and Table 6 show the results of those studies. All-season averaging has eliminated our concerns over disequilibrium between air and vegetation (seasonal air/vegetation $=0.97 \pm 0.11$ ). Input of root-stored lower specific activity carbon in the early weeks of the growing season provides a possible explanation for the discrepancies noted in May-June, as does great variability in the air emissions measured during part of that period (Table 5). Plant sugars are made and stored rapidly; we have observed that $>5 \%$ of a plant leaf's carbon content may be

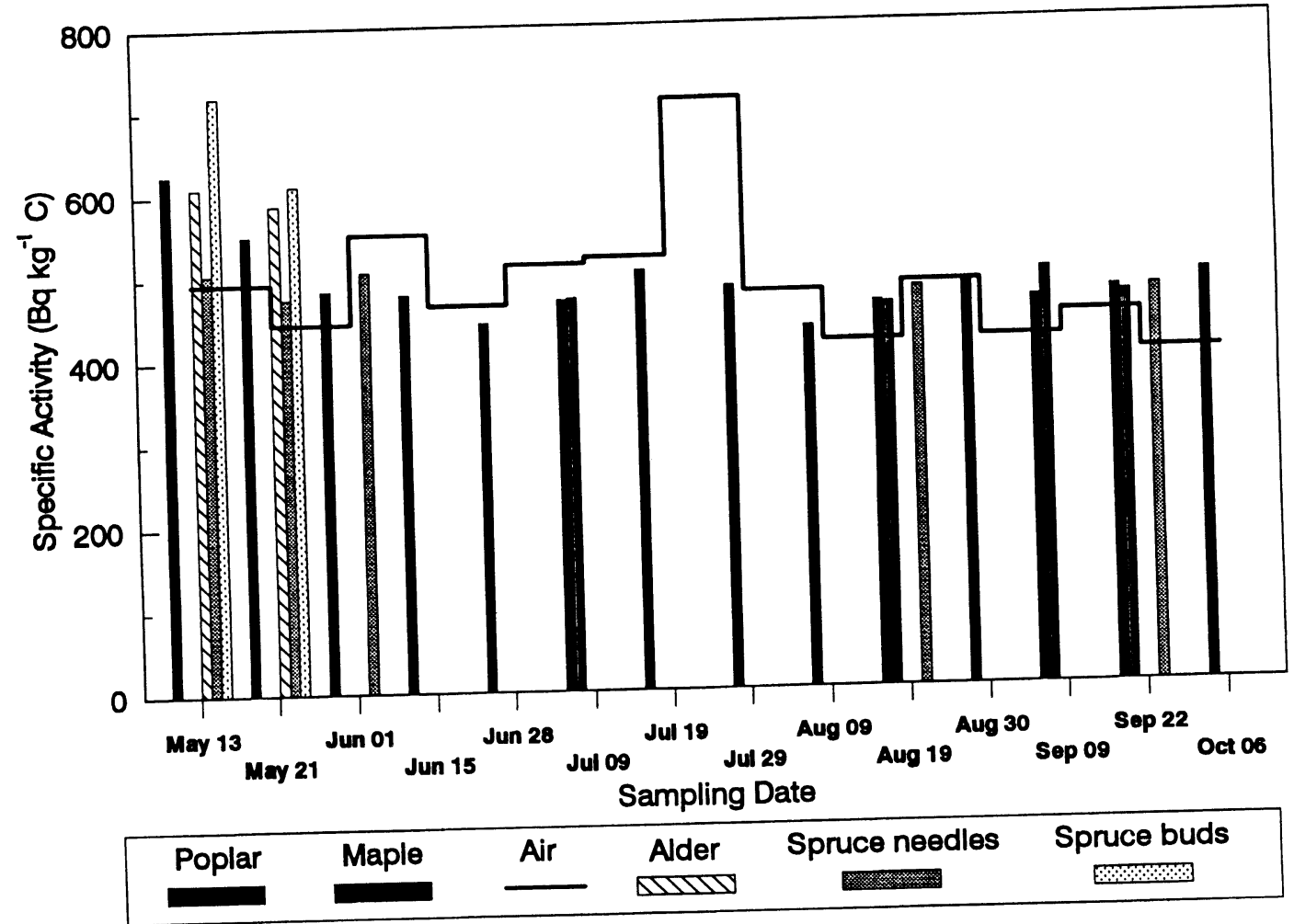

Fig. 5. Specific activity of ${ }^{14} \mathrm{C}$ in air and in several plant species at one location, over a full growing season 
replaced over a day (Milton and Enright, ms.). The uncertainty introduced by 24-h air sampling, rather than daylight hours only, has been less conclusive. Such differences, when observed, may mainly be attributable to the bias towards lower inversion heights during night-time.

TABLE 6. Changes in ${ }^{14} \mathrm{C}$ Levels (in $\mathrm{CO}_{2}$ ) in Air with Time of Day

\begin{tabular}{|c|c|c|}
\hline \multirow[b]{2}{*}{ Sampling period } & \multicolumn{2}{|c|}{ Sampling location } \\
\hline & Station $1^{*}$ & Station $2 \dagger$ \\
\hline $\begin{array}{l}06 / 30 / 94 \text { to } 07 / 07 / 94 \\
\text { Nights (21:00-5:30) } \\
\text { Days (5:30-21:00) } \\
\text { Average (weighted) } \\
\text { Days/average } \\
\text { Night/average }\end{array}$ & $\begin{array}{l}338 \ddagger \\
378 \\
364 \\
1.04 \S \\
0.89\end{array}$ & $\begin{array}{l}409 \\
522 \\
482 \\
1.08 \\
0.78\end{array}$ \\
\hline $\begin{array}{l}\text { 07/07/94 to 07/14/94 } \\
\text { Nights (21:00-5:30) } \\
\text { Days (5:30-21:00) } \\
\text { Average (weighted) } \\
\text { Days/average } \\
\text { Night/average }\end{array}$ & $\begin{array}{l}485 \\
388 \\
421 \\
0.92 \\
1.25\end{array}$ & $\begin{array}{l}550 \\
411 \\
460 \\
0.89 \\
1.34\end{array}$ \\
\hline $\begin{array}{l}\text { 07/29/94 to 08/09/94 } \\
\text { Days (6:00-20:30) } \\
\text { Average (total 24-h sample) } \\
\text { Nights (calculated) } \\
\text { Days/average } \\
\text { Nights/average } \\
\end{array}$ & $\begin{array}{l}339 \\
372 \\
423 \\
0.91 \\
1.14\end{array}$ & $\begin{array}{r}470 \\
455 \\
431 \\
1.03 \\
0.95\end{array}$ \\
\hline
\end{tabular}

To provide a more complete history of ${ }^{14} \mathrm{C}$ emissions at this site, we have started to accumulate treering chronologies. We separated and partially analyzed cross-sections of two trees; Figure 6 shows the data obtained to date, along with the NRU power history for the same period. The fluctuations in these data indicate that the major increases and decreases in measured ${ }^{14} \mathrm{C}$ content correlate fairly well with variability in NRU power production. NRX was probably less important, though the data covering 1990, when it was operated almost continuously during an NRU shutdown period, would seem to contradict that statement. As a serious leak of moderator from NRU occasioned that shutdown, it is difficult to assign responsibility for the high value in the tree ring for that year. Comparison with data for the second tree, which was growing $c a .0 .5 \mathrm{~km}$ away, and at differing distances from the reactor stack and the reactor building roof vents, may help us to determine the chief mode of ${ }^{14} \mathrm{C}$ release at this site.

\section{Accumulation in Soils}

We took soil cores to a depth of $30 \mathrm{~cm}$ at many locations at both sites. We analyzed several of these from each site in 2-cm sections for bulk density and loss on ignition (wt \%), and used the method of Harkness, Harrison and Bacon (1986) to assess the relative distribution of "old" (heavy) and "young" (light) carbon in the two profiles. While the PNGS plot indicated the presence of two different carbon components, the heavy carbon component of the CRL soil was either very small or 
non-existent. Density fractionations down one PNGS core have indicated that below $10 \mathrm{~cm}$, the bulk of the carbon has a density (d) $>1.7$, with a significant portion of the carbon throughout the profile $(>6 \%)$ in the $d>2.7$ fraction. Similar fractionation of the CRL core showed that most of the carbon present has a density $<1.7$, and the percent carbon in the denser material is $<1 \%$. Below $10 \mathrm{~cm}$, the matrix is almost pure sand. Because denser carbon fractions are usually more refractory and less subject to degradation than the light fractions, this density difference between the two soil types in the uppermost section of the cores suggests a much shorter turnover time for the carbon at Chalk River, with little buildup of a long-term carbon pool.

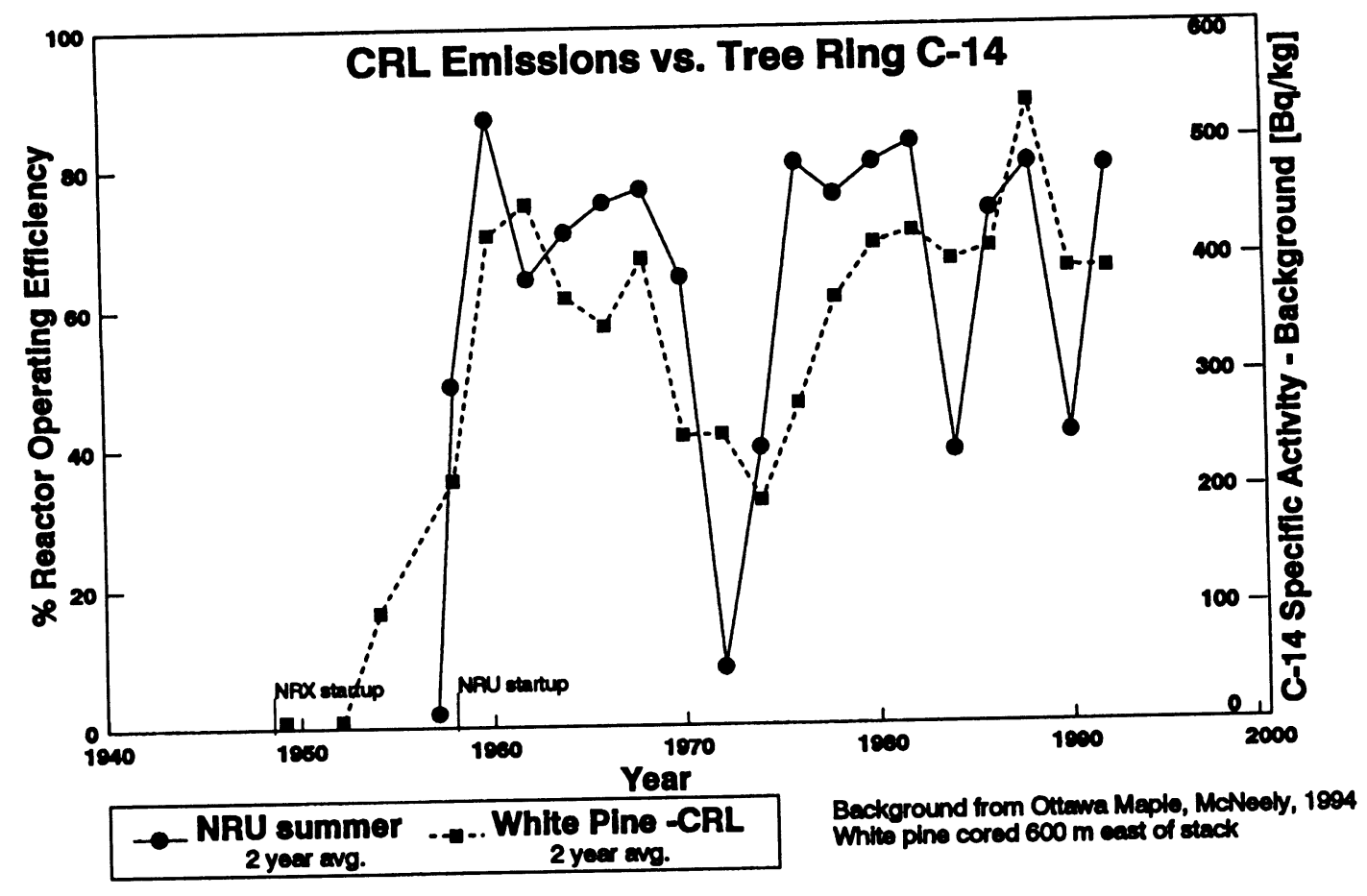

Fig. 6. A tree-ring chronology of ${ }^{14} \mathrm{C}$ emissions at CRL, with the NRU reactor power production recorded over the same period (1952-1992)

A comparison of the depth of incursion of ${ }^{14} \mathrm{C}$ and ${ }^{137} \mathrm{Cs}$ atmospheric fallout from weapons testing in the 1950s and 1960s can indicate the action on carbon of processes other than surficial deposition, e.g., bacterial degradation and remobilization as soil gas, dissolved organic carbon, etc., which can move the carbon to greater depths. ${ }^{137} \mathrm{Cs}$ is discernible to $16 \mathrm{~cm}$ in the PNGS cores, in good agreement with the $20 \mathrm{~cm}{ }^{137} \mathrm{Cs}$ incursion reported by Trumbore (1993) for a Utisol from the Sierra Nevada, California; ${ }^{137} \mathrm{Cs}$ was not detected below $10 \mathrm{~cm}$ at $\mathrm{CRL}$. The higher-than-average specific activity at the very top of the CRL core suggests that $\mathrm{Cs}$ is very highly retained in this sandy matrix. ${ }^{14} \mathrm{C}$ profiles for the two soils are plotted in Figure 7. Levels well in excess of those generated during weapons testing are present to the full depth of the Pickering core. The lower specific activities of ${ }^{14} \mathrm{C}$ measured in the CRL profile permits reactor emission penetration to be unequivocally identified to a depth of $10 \mathrm{~cm}$ only. Weapons testing and reactor inputs were mixed at this site; comparison with "background" cores will be required if we wish to unravel the two sources at greater depths. Measurement of the ${ }^{14} \mathrm{C}$ in the various density fractions will provide us with a better understanding of the carbon dynamics in these soils. Turnover times for the respective carbon pools will be calculated using existing models. 
Using the core analyses performed to date, we have made a rough assessment of the ${ }^{14} \mathrm{C}$ sequestered in these soils and compared those values with estimates of total bioaccumulation of ${ }^{14} \mathrm{C}$ at the coring site during the lifetime of reactor operations. Within the range of net primary productivity recommended for these two regions by Whittaker and Likens (1973), ratios of 0.15-0.35 for PNGS soil, and $0.047-0.11$ for CRL soil are calculated. These estimates lend additional support to our assumption of very rapid carbon turnover rates in the CRL soil. Preliminary tests are underway to set limits on the extent of carbon losses via soil respiration.

\section{Conclusion}

Two Canadian sites of chronic release of low-level amounts of ${ }^{14} \mathrm{C}$, in different climatic and soil zones, are being compared for the extent of atmospheric dispersion of ${ }^{14} \mathrm{CO}_{2}$, biomass accumulation and accumulation in soils. Our investigations have helped us to address several research questions. We have shown that although good emission records are probably not available in most cases, power production records and tree-ring chronologies, for example, can replace continuous monitoring data, so long as the user is fully cognizant of the shortcomings of the method. The assumption that the ${ }^{14} \mathrm{C}$-specific activities of air and vegetation are always in equilibrium is not necessarily valid in the immediate vicinity of reactor emissions, and hence, short-term air and vegetation measurements must be viewed with caution. ${ }^{14} \mathrm{C}$ is accumulating in local soils, and biomass accumulation records derived from tree- ring chronologies, combined with measured dilution factors, can provide approximations of the total amounts of ${ }^{14} \mathrm{C}$ deposited locally on the surfaces of these soils. These in turn can be compared with present soil inventories of ${ }^{14} \mathrm{C}$ to provide new insights into the roles of remobilization and sequestering of carbon in soils.

The end product of these measurements will be improved parameter inputs for modeling, allowing more realistic assessment of the local doses resulting from nuclear power production. We also recognize that to estimate questions of global dose, tree-ring and soil chronologies may be inadequate, due to limitations of the growing season. Better techniques are required for year-round passive air monitoring. 


\section{ACKNOWLEDGMENTS}

This work has been carried out under the financial support of the CANDU Owners Group. Helpful discussions with J. Lamarre, R. Maruska and R. J. Cornett are gratefully acknowledged.

\section{REFERENCES}

ACRP-14, Advisory Committee on Radiological Protection, Canadian Atomic Energy Control Board, Principles for the Regulation of Carbon-14 in Effluents from Canadian Nuclear Facilities 10, Fig. 3, in press.

Cain, W. F. and Suess, H.E. 1976 Carbon-14 in tree rings. Journal of Geophysical Research 81(21): 3688-3694.

Curtis, K. and Guest, A. 1988 Carbon-14 emission monitoring of the Bruce nuclear power development incinerator exhaust stack. In Proceedings of the International Conference on Incineration of Hazardous, Radioactive and Mixed Wastes. CONF 880526: 1-10, University of California, Irvine.

Harkness, D. D., Harrison, A. F. and Bacon, P. J. 1986 The temporal distribution of bomb ${ }^{14} \mathrm{C}$ in a forest soil. In Stuiver, M. and Kra, R. S., eds., Proceedings of the 12th International ${ }^{14} \mathrm{C}$ Conference. Radiocarbon 28 (2A): 328-337.

Jenkinson D. S., Harkness, D. D., Vance, E. D., Adams, D. E. and Harrison, A. F. 1992 Calculating net primary production and annual input of organic matter to soil from the amount and radiocarbon content of soil organic matter. Soil Biology and Biochemistry 24(4): 295-308.

Joshi, M. L., Ramamirtham, B. and Soman, S. D. 1987 Measurement of ${ }^{14} \mathrm{C}$ emission rates from a pressurized heavy water reactor. Health Physics (52): 787-791.

Kabat, M. J. 1979 Monitoring and removal of gaseous carbon-14 species. In Proceedings of the 15th DOE Nuclear Air Cleaning Conference. CONF-780819-P1: 208-230.

Levin, I., Kromer, B., Barabas, M. and Munnich, K. O. 1988 Environmental distribution and long-term dispersion of reactor $\mathrm{CO}_{2}$ around two German nuclear power plants. Health Physics 54(2):149-156.

Maruska, R. 1981 A correlation of measured carbon-14 emissions and station operating parameters. Ontario Hydro Report RMEP-IR-03483-1, with addendum 1982.

McNeely, R. 1994 Long-term environmental monitoring of ${ }^{14} \mathrm{C}$ levels in the Ottawa region. Environment International 20(5): 675-679.
Milton, G. M. and Brown, R. M. 1993 A review of analytical techniques for the determination of carbon-14 in environmental samples. AECL Report 10803.

Milton, G. M. and Enright, S. (ms.) Uptake of carbon-14 by plants. 1994 Deep River Science Academy Project. AECL Report, in preparation.

Neil, B. C. J. 1983 Carbon-14 in biota from the vicinity of Ontario Hydro nuclear generating stations. Ontario Hydro Safety Services Department Information Report SSD-IR-83-21.

O'Brien, B. J. 1984 Soil organic carbon fluxes and turnover rates estimated from radiocarbon enrichments. Soil Biology and Biochemistry 16(2): 115-120.

Otlet, R. L. (ms.) 1992 Carbon-14 in the local environment around BNFL, Sellafield. Paper presented at a Workshop on the Environmental Behaviour of Carbon-14 Nov. 1992, Ottawa. AECL Report RC-1009.

Otlet, R. L., Longley, H. and Walker, A. J. 1989 Measurements of carbon-14 in tree rings from trees growing in the Sellafield area. Part 13, Studies of Environmental Radioactivity in Cumbria AERE-R 12362.

Otlet, R. L.,Walker, A. J. and Fulker, M. J. 1990 Survey of the dispersion of ${ }^{14} \mathrm{C}$ in the vicinity of the UK reprocessing site at Sellafield. Radiocarbon 32(1): 23-30.

Trumbore, S. E. 1993 Comparison of carbon dynamics in tropical and temperate soils using radiocarbon measurements. Global Biogeochemical Cycles 7(2): 275290.

Uchrin, G., Csaba, E. Hertelendi, E., Ormai, P. and Barnabas, I. $1992{ }^{14} \mathrm{C}$ release from a soviet-designed pressurized water reactor nuclear power plant. Health Physics 63(6): 651-655.

Wahlen, M. and Kunz, C. $0.1978{ }^{14} \mathrm{C}$ activity and distribution in gaseous effluents from pressurized water reactors. Transactions of the American Nuclear Society 30: 113-114.

Whittaker, R. H. and Likens, G. E. 1973 Carbon in Biota. In Woodell, G. M. and Pecan, E. V., eds., Carbon and the Biosphere. U.S. Atomic Energy Commission CONF720510. 